\title{
Research "Fitting" Practice: Firth and Wagner, Classroom Language Teaching, and Language Teacher Education
}

\author{
DONALD FREEMAN \\ University of Michigan \\ School of Education \\ 610 East University, Room $1228 B$ \\ Ann Arbor, MI 48109-1259 \\ Email: donaldfr@umich.edu
}

\begin{abstract}
This article argues that Firth and Wagner's 1997 contribution gained influence in second/foreign language teaching partly owing to a loose group of conceptual and ideological preconditions that drew on classroom methodologies, debates over educating second language teachers, and new views of how teachers could document and analyze their own practices. The article is organized around four issues drawn from Firth and Wagner: focus (How was classroom language teaching refocused by their critique?); meaning (What is the nature of meaning as the central driver in instructed learning?); locus (Given the preceding questions, how then does the locus of activity in the language classroom shift?); and identities (How are the notions of learner and teacher identities reshaped by this critique?). The discussion draws connections between the thinking articulated by Firth and Wagner and the practices of classroom language teaching, and includes suppositions that are susceptible to further investigation.
\end{abstract}

\section{A LANDSCAPE OF INCOMPATIBILITY}

The idea that theorizing in second language acquisition (SLA) research has never really fit classroom language teaching ${ }^{1}$ has been a point of ongoing discussion for decades (Firth \& Wagner, 1998; Ortega, 2005). Although some might argue otherwise, SLA research, writ large, has actually had only a modest impact over the years on the classroom practices of language teaching (Katz \& Watzinger-Tharp, 2005). To be sure, there have been periods in second/foreign language education during which such research has been an ascendant influence. From time to time, scholarship on language teaching methodology (e.g., Brown, 1987; Omaggio Hadley, 1993) and on language curriculum design (e.g., R. K. Johnson, 1989) has shown the persuasiveness of

The Modern Language Journal, 91, Focus Issue, (2007) 0026-7902/07/893-906 \$1.50/0

(C)2007 The Modern Language Journal research findings from SLA on these domains. However, overall, it is hard to claim that language teaching has been a practice informed by research.

This is a somewhat perplexing state of affairs, because understanding how people, whether adults or children, learn languages beyond their first or mother tongue should arguably be the centerpiece of any language teacher's craft. Certainly in terms of professional preparation, this knowledge should play an important role in the education of individuals who intend to become language teachers. In the main, however, the work of language teaching seems not to have been widely affected by this important and relevant domain of knowledge.

The foregoing is offered as a characterization of the status quo; it is not a position that I wish to argue for (or against). I come to these discussions as a language teacher educator and as someone who is concerned with how language teachers learn (through professional preparation) and change 
(through professional development) their classroom practices. In this regard, questions about how language learning is understood and defined, both inside and outside the classroom, are central both to classroom instruction and to educating individuals as language teachers. Although there is not-and will never be-a unidirectional flow of knowledge from research to practice, the two endeavors are clearly linked and therefore should be to some extent mutually informing. Research offers classroom practice one set of explanations; it defines what counts as valid in understanding language learning processes as the basis for instruction, curriculum, and assessment. But as we know, classroom practice is not itself simply a vehicle; it is, like language, to gloss Bahktin's (1981) famous phrase, "overpopulated with the intentions of others" (p. 294). Therefore, the compatibility of SLA research and classroom practice-how they fit one another-has to be a central concern to researchers, to teacher educators, and to teachers.

Over the years, there has been much speculation about this lack of compatibility, or lack of fit, between SLA research and classroom teaching. The relationship has been characterized in archetypal terms by a contention of distance between the two domains. In this view, theory and practice are mutually alienated. The dichotomy situates research knowledge as entirely theoretical and abstracted from context, while classroom practices are intensely local and instrumentally oriented to a specific time and place (Clarke, 1994; K. E. Johnson, 1996). At its core though, the argument is about the knowledge base of language teaching, where it originates and how it is defined. The polarity of research and practice anchors that knowledge base and its antecedents in SLA research on the one hand, in praxis on the other, or perhaps in some dialectical synthesis of the two. Any way the argument is slanted however, the polarity leads to a view defined by deficiency in which one form of understanding lacks what the other has. So research needs to have practical application to reach the classroom, whereas knowledge from praxis needs some sort of theory or conceptual framework to make claims of validity, generalizability, and reliability.

The last decade has bridged that divide by raising questions about the diversification of the knowledge base of language teaching, arguing in essence that instructional practices are based on a set of understandings wider than those only derived from SLA research (Freeman \& Johnson, 1998). The movement of knowledge and understanding from research to teaching has likewise been challenged by arguments that teachers themselves can, and do, generate knowledge of practice using procedures according to warrants of validity and generalizability appropriate to their roles and experiences (Cochran-Smith \& Lytle, 1993). In this view, the major obstacles to the compatibility between research and practice include the relative difference in perspective and professional position of researchers and teachers, as well as differences in research procedures that can lead to a perceived lack of direct connection, often called relevance or applicability, between SLA research findings and language classroom praxis.

Contributing to this lack of connection between research and classroom instruction has been a long-held perception that language teachers' practices are somehow inherently unique, owing primarily to the nature of their subject matter (Borg, 2005; K. E. Johnson, 1999). Candlin and Widdowson (1988), leading teacher educators and applied linguists, expressed this view in the introduction to their major series, Language Teaching: A Scheme for TeacherEducation, published in the late-1980s:

We believe that advances in language teaching stem from the independent efforts of teachers in their own classrooms. This independence is not brought about by imposing fixed ideas or promoting fashionable formulas. It can only occur where teachers, individually or collectively, explore principles and experiment with techniques. (p. viii)

This independence of practice, and the perceived gap between the research and classroom perspectives, contributed to a space in which a different view of SLA theory might take hold, a view that might be more compatible with the experience of language teaching and the methodologies that supported that experience.

It was into this general landscape of relative lack of compatibility between SLA research and classroom practice, combined with emerging views of teachers as thoughtful operators, that Firth and Wagner's 1997 article, “On Discourse, Communication, and (Some) Fundamental Concepts in SLA Research," introduced its broader critique. In raising questions such as, How might such central constructs as meaning and language competence be redefined? How could learner identity and success be understood differently? At its most basic, is second language learning better understood as an individual or a social undertaking?, their article catalyzed a set of issues that congregated around the knowledge base of language 
teaching. In so doing, they argued for a different set of conceptual boundaries both within the classroom and between the classroom, or instructed second language learning setting, and the world (of noninstructed settings). It is interesting that these boundaries were actually better suited to the understandings of classroom practice that were emerging.

In a sense, Firth and Wagner's 1997 article redescribed the territory, or spaces, in which instructed language learning was seen to take place. Spaces that had been seen as largely internal to the learner, and therefore private, they argued, could be seen as interactional and thus publicly accessible to both study and intervention. Concepts, such as meaning and communicative intent, that had been defined a priori, could be seen as open to mutual negotiation among learners and between learners and the teacher. And the basic metric that had defined language learning in terms of what the individual could (or could not) do might more appropriately be understood using Stevick's (1980) classic phrase of almost two decades earlier as "what goes on within and between people" (p. 5).

\section{THE PREMISE}

This article examines these shifts in thinking as spaces for reconceptualizing key aspects of language teaching/learning processes in classrooms. I want to suggest that Firth and Wagner's 1997 articulation of different constructs for SLA research supported-and was informed by-the ways in which language teaching practices and teacher education had been conceived at least a decade before their critique appeared. Their arguments about the nature and definition of second language learning took hold, I would contend, through an existing conceptual climate in language teacher education, which makes certain sense because teacher preparation offered a key venue for their application. Absent the environment of implementation that teacher training programs and the preparation of new language teachers provided, the 1997 article, and its attendant controversies, might have had less long-term influence. This Focus Issue and the articles it contains, which are devoted to examining these influences a decade later, suggest that their arguments have contributed to realizing different directions in SLA research.

I would argue that Firth and Wagner's (1997) article took hold in part because of a set of preconditions. These preconditions, which were conceptual or even ideological, grew largely out of the debates over educating language teachers (Freeman \& Johnson, 1998; Yates \& Muchisky, 2003) and out of new contentions about the ways in which teachers could document and analyze their own practices through teacher-research and action research (Freeman, 1998; Nunan, 1989). Together this loose ideological backdrop helped to position-and even instantiate-Firth and Wagner's critiques in the field of second/foreign language education generally.

This article then is largely a discussion of ideas. To organize my comments, I use four issues drawn from the Firth and Wagner 1997 article to relate their view of SLA theory to the classroom practices in language teaching prevalent in the period. These four issues are (a) focus: How is classroom language teaching refocused by their critique?; (b) meaning: What is the nature of meaning as the central driver in instructed learning?; (c) locus: Given the preceding questions, how then does the locus of activity in the language classroom shift?; and (d) identities: How are the notions of learner and teacher identity reshaped by this critique?

With each of these issues, I examine how views of language teachers' practices, understood principally through classroom teaching methodologies, anticipated and supported the critiques advanced by Firth and Wagner (1997). My premise is that the thrust of their critique helped to substantiate a critical space that supported a different "fit" between SLA research and classroom practice. I will acknowledge that the argument is a speculative and conceptual one, drawing together work in teacher learning (e.g., Freeman, 2002), cognition (e.g., Borg, 2003), and language teacher education (e.g., Freeman \& Johnson, 1998). As such, the discussion includes suppositions that are susceptible to further investigation. The aim, however, is to draw connections between the thinking articulated by Firth and Wagner and the activity of classroom language teaching.

\section{CONCEPTUAL PRECONDITIONS ${ }^{2}$}

In many ways, the mid-1990s marked a watershed in rethinking how people learned to be language teachers. During this period, there was a confluence of three streams of thinking: a rather new research direction that examined how people learned to be language teachers (e.g., Freeman \& Richards, 1996; Kleinsasser, 1992); discussions about the role and design of language teacher education practices (Richards \& Nunan, 1990); and the ascendance of action and teacher research (Nunan, 1989). In interconnected ways, these three influences argued for a view of language 
teachers and of language teaching that differed in profound ways from their antecedents. Teachers, who had been seen as recipients of knowledge from research and theory and as implementers of teaching methods and curricula, were now being accorded status as thinkers, decision-makers, and problem-posers. This redefinition of role ranged from politically expansive positioning advanced by critical theorist Giroux (1988), who argued for teachers as transformative intellectuals, to the more pragmatic positioning of teachers as independent thinkers (Candlin \& Widdowson, 1988) mentioned previously. However all these views shared a common recognition of what Walberg (1971) had called teachers' mental lives.

Against this backdrop came Firth and Wagner's (1997) critique. Although their arguments created a great deal of discussion, and even some consternation, in the SLA research community, their article had relatively little impact (in terms of changing what went on) in classrooms. It could be argued that this lack of interest was just further evidence of the basic disconnect between SLA research and language teaching, or it might be attributed to resistance on the part of language teachers, administrators, and institutions to progress in understanding of language learning. This article suggests an alternative analysis, however. I would contend that prevailing language teaching methodologies of the day, linked with emerging conceptualizations of language teaching and of language teachers, had anticipated the theoretical positions put forward in Firth and Wagner. Thus, in a real sense, praxis created preconditions that facilitated the reframing of classroom language learning that their article suggested.

Since the advent of audiolingualism (ALM) in the 1960s, classroom teaching methodologies have tried to emulate language learning outside the classroom, in what SLA researchers would call noninstructed settings. The explanatory aim has been to locate and describe the drivers or key elements of these noninstructed learning processes, and then to re-create them in the classroom (or instructed setting) through particular instructional practices. These practices then create a focus for classroom language teaching, be it the behavioral view of habit in ALM or, in the methodologies that followed, the notion of how learners created, communicated, and understood meaning in the new language. This shift in focus-from language as behavior to language as meaning-redefined the locus of engagement in the classroom, the space in which the processes of language teaching and learning connect with each other, and, in turn, the ways in which the identities of teacher and learner are understood in those processes. As Bruner (1996) observed in commenting on how the activity of teaching, and taking part in it as a learners, inherently projects identities onto participants:

Any choice of pedagogical practice implies a concep-
tion of the learner and may, in time, be adopted
by him or her as the appropriate way of thinking
about the learning process. For a choice of pedagogy
inevitably communicates a conception of the learn-
ing process and the learner. Pedagogy is never in-
nocent. It is a medium that carries its own message.
(p. 63 )

Although the SLA research critiqued by Firth and Wagner (1997) was largely concerned with language learning in instructed settings, language teachers and teacher education programs were already working with methodologies that had articulated many of the views that Firth and Wagner were proposing because these teachers were working with classroom methodologies anchored in learning theories from beyond the classroom. I would argue, therefore, that this confluence of circumstances helped to (re)orient SLA thinking to what was already central in most classroom practice.

\section{FOUR ISSUES}

\section{Half Full or Half Empty: What Is the Focus of Classroom Language Teaching?}

Firth and Wagner (1997) articulated a key dilemma in understanding the focus of instructed language learning that went to the heart of the thinking about communicative deficiency that was shaping the field. They noted that beyond the conventional examination of failures in communication, it could be beneficial to look at successes as well: "We suggest that a study of communicative successes-in addition to perceived failures or problems-may provide new and productive insights for SLA" (p. 289). In so doing, they suggested moving the study of instructed language learning away from a singular focus on deficiencies, seeing the glass half empty, to an approach that considered possibility as well, seeing the glass half full.

The shift to thinking in terms of communicative successes challenged the deep-seated legacy of ALM theory of learning as habit formation, and opened research to a broad range of individual and social constructivist views of the process. In an interesting way, Firth and Wagner's (1997) 
critique echoed Chomsky's challenge to behaviorism as a dominant theory for classroom instruction of more than three decades earlier. Addressing the Northeast Conference on Language Teaching in 1965, he contended quite forcefully (as cited in Blair, 1982) that there was a disconnect between language teaching and its theoretical base:

A good deal of foreign language instruction... going on now... is based on a concept of language... [which assumes that it] is a system of skills that ought to be taught through drill and the formation of S-R associations. I think the evidence is quite convincing that that view of language is entirely erroneous, and it's a very bad way-certainly an unprincipled way-to teach languages. If it happens to work, it would be an accident for some other reason. (p. 5)

Asserting rather categorically that classroom practices were out of sync with linguistics knowledge of the day, Chomsky saw a need to move beyond the image of learning that had anchored the ALM view of habit-formation and errors as potentially damaging behaviors that could impede successful outcomes and language proficiency.

It is interesting that the operational challenge to the ALM view of learning as remedying deficiencies actually arose from the so-called humanistic teaching methodologies, which gained ground initially not in the area of teaching English to speakers of other languages (TESOL) but in foreign language teaching (Blair, 1982). These approaches, which originated in the 1970s (e.g., Curran's, 1976, Community Language Learning; Gattegno's, 1976, Silent Way; Lozanov's Suggestopedia, as cited in Stevick, 1980) were based on theory and research on language learning in noninstructed settings. Thus they emphasized the creative or generative (as contrasted with habitual) views of language learning that Chomsky (1959) advocated. Although many of the specific applications of these methodologies lost their persuasiveness in the $1980 \mathrm{~s}$, the thinking they represented clearly shaped the pedagogical landscape of classroom language instruction in important ways (Stevick, 1980). For the most part, these methodologies, like the more general movement to communicative language teaching or CLT (e.g., Brumfit \& Johnson, 1979) that followed in the 1980 s, placed a clear emphasis on communicative successes.

Perhaps in reaction to this focus on successful language learning, the common critique of the period was that the assertions of the humanistic methodologists were theoretically marginal, and could not be properly anchored in research knowledge. These criticisms depended, however, on how research was defined. In the 1960s in the era of ALM, or of grammar-translation before that, the relationship between research and practice had been on firmer ground. In focusing on learning, ALM teaching, for example, had a singular theoretical foundation that drew directly from Skinnerian psychology (Richards \& Rodgers, 1986). Grammar-translation was based on a coherent view of content, drawing on theories of grammar, linguistic form, and language equivalence to support the classroom practices of translation (Kelly, 1976). ${ }^{3}$ Thus, as classroom methodologies, these two approaches were each anchored in their corresponding unified theoretical frames, and there were researchable propositions that flowed from these theories. In both cases, however, the foundations came from outside the immediate field of applied linguistics and certainly outside instructed settings of learning.

Beginning in the 1970s, the advent of the humanistic approaches dismantled this notion of a single, unified theoretical frame for methodology. Challenging the deep-seated ideas of deficit were the emphases on communicative successes and on learners as constructors of meaning that underpinned the Silent Way, Community Language Learning, and Suggestopedia as classroom teaching methodologies. The definitions of such success, and the learning theory underlying it, were based in research traditions unique to each approach. Gattegno's (1987) work on the Silent Way referred to European developmental psychology, which he recast in his own version of the science of education. Curran's (1976) educational approach, Counseling-Learning, as implemented in the classroom in Community Language Learning, drew directly from U.S. counseling psychology in the work of Rogers. Furthermore, Lozanov's (Lozanov \& Gateva, 1988) Suggestopedia was based in Soviet parapsychology and so-called superlearning theory.

Just as their predecessors had done, all three methodologies based their theories on descriptions of learning in noninstructed settings, which they then applied to foreign/second language learning in classrooms. Thus, it was probably not accurate to assert, as some contemporary critics did (e.g., Seliger \& Long, 1983), that these methodologies were not based in research and theory. Perhaps it is better to inquire about the theories or research in which they were anchored. And furthermore, why might these foundational theories be attractive as bases for classroom practice? 
No doubt part of the issue lay in the fact that SLA itself was a nascent enterprise in the 1960s and 1970s (Larsen-Freeman \& Long, 1989). Given its developing scope, it would probably have been overly ambitious to claim that such research alone could inform classroom language teaching instruction. In addition, because they often focused on the early years, first language acquisition studies were usually examinations of language learning in noninstructed settings; therefore, they tended to have limited direct applicability to classroom second language instruction. Nonetheless, there was a certain passion in making the bridge between theory and teaching. An early SLA theorist, McLaughlin (1987) captured the excitement, and even bravado, of that period in studying language learning when he observed in the introduction to his book, Theories of Second Language Learning:

Advances in the areas of general linguistics, psycholinguistics, and cognitive psychology have prepared the groundwork for the study of second-language learning. During the past two decades, there has been an enormous increase in our knowledge of the process of language learning in young children. All over the world, researchers follow young children with their tape recorders or video recorders gathering information on their linguistic and cognitive development. As more is learned about the process of first-language development, hypotheses are generated to stimulate second-language learning in children and adults. (p. 1)

As the research territory opened, the unified account provided by the learning theory of behaviorism that anchored the classroom practices of ALM, was further challenged. What had been deconstructed methodologically now came under fire theoretically. In its place, a focus on (and pluralistic definitions of) communicative success, and interlocutors' roles in creating it, started to emerge. But the order of emphasis was different. On the one hand, classroom practices, which were increasingly informed by the humanistic methodologies of the 1970s and 1980s, drew on learning theories that addressed learning first and language second. On the other hand, studies of language learning sought to bridge the focus on noninstructed settings inherent in most research on first language acquisition and literacy with the need to understand second language learning in classrooms better. Thus, they focused first on language, and second on similarities and differences in how it was learned in these two settings. In emphasizing learning, many of the assumptions of humanistic methods far outstripped not only the levels of research study and understanding in SLA of the period, but even more critically, the theoretical frames used to advance such research. So, as the development of SLA met the articulation of humanistic methods throughout the 1980s, the lack of "fit" between that research and existing teaching practices was increasingly evident.

\section{The Nature of Meaning: What Is Actually Being Taught/Learned in the Language Classroom?}

Firth and Wagner (1997) made the point that a view of second language communication anchored in deficiency, one that focused on learners' mistakes and communicative failures and did not consider their successes, presented a skewed view not only of their abilities with the new language but also quite possibly by extrapolation their reasons in using it as they did. If one took the opposite view-that learners knew what they were doing as they used the new language-then they might well be expressing themselves and their perceptions rather than simply acting as deficient communicators. As has been pointed out, Firth and Wagner's argument was not an entirely new one. In SLA research, the distinction between $e r$ rors, which can be described systematically, and mistakes, which appear to be unsystematic (Allen \& Corder, 1973), as applied through the processes of error analysis (Richards, 1975), and conceptualized more broadly by the notion of the interlanguage continuum (Selinker, 1972), helped to underscore, at least theoretically, such a developmental view of language learning. However, this developmental view was anchored in concepts of linguistic accuracy, proficiency, and mastery that all assumed a potential flawless, fully communicative performance. In challenging this assumed endpoint, Firth and Wagner's analyses aligned with prevalent instructional practices.

This line of reasoning was already well established in language teaching and in language classroom practices themselves, through the debate on mistakes and correction. Whereas ALM had characterized learners' mistakes as behaviors to be eradicated because they could be damaging to their progress in language learning (Richards \& Rodgers, 1986), the humanistic methodologies introduced the notion that these same mistakes might play important roles in learning. In the 1970s, these methodologists, just as their SLA counterparts would do, asserted that these mistakes could be potential windows into student learning.

The link between mistakes and the language learner was the conception of meaning, and it was 
here that Firth and Wagner's 1997 contentions helped to bring research constructs with classroom practices into greater alignment. When they argued that, "Meaning. . . is not an individual phenomenon consisting of private thoughts executed and then transferred from brain to brain, but a social and negotiable product of interaction, transcending individual intentions and behaviors" (p. 290), Firth and Wagner were helping to reframe the notion of language learners (and ultimately teachers) as autonomous and individual actors. Instead, they advanced a social perspective on language learning, one that coincided well with the evolving view of classroom teaching.

The transformation actually started with humanist methodologies in the mid-1970s, when Gattegno (1976) suggested that mistakes might provide insight into learners' construction of meaning, and Curran (1976) proposed that these mistakes could be anchored in the meanings or worlds the learners were trying to express. Both views drew on assumptions about language, and more specifically, on assumptions about how meaning might be addressed in classroom instruction. In a sense, these methodologists foreshadowed Firth and Wagner's (1997) assertion two decades later that meaning "is a social and negotiable product of interaction, transcending individual intentions and behavior" (p. 290). In his book, The Commonsense of Teaching Foreign Languages, Gattegno (1976) observed: "That words do not convey meaning by themselves is at once clear if one switches to listening to a language one does not know. Words are arbitrary, but they are also consistent, and it is the perception of consistency that offers a basis in our mind for retention" (p. 3). Curran (1976) made a similar observation in Counseling-Learning in Second Languages that, “'Meaning' gives a person his [sic] field of options, pointing him to areas of possible choice and self-investment" (p. 9).

In both methodologies (Silent Way and Counseling Learning), and in others of the period, such as Total Physical Response and Suggestopedia (Larsen-Freeman, 1986), this understanding of the central role of meaning as an interactive phenomenon translated more or less directly into techniques of error correction (Omaggio Hadley, 1993). In these classroom practices, the intentions and meanings that learners were trying to express were key. These methodologies challenged the normative view passed on from ALM (and often reenforced in SLA research constructs of the day) that focused error correction on linguistic form. In contrast, the humanistic methodologies of the 1980s, and the communicative language and proficiency-oriented teaching that followed in the 1990s, recast the teacher's role. Broadly put, the job was to focus on what learners were trying to say and to match target language forms with their communicative intent. In this sense, learning, or the intent to make meaning, preceded language use.

Perhaps the clearest example of this view of meaning as contingent on interaction and intent could be found in Krashen's (1981) concept of comprehensible input, which was widely cited in the 1980s and became the conceptual basis of the Natural Approach (Krashen \& Terrell, 1983). Arguing that learners could learn only from language input that they could make sense of, Krashen (1981) created a construct that linked meaning to use. Though in some ways tautological-learners learned from what made sense to them, and what made sense to them was defined as input from which they learned-comprehensible input, and the companion constructs of $i+1$ and the affective filter, provided a rationale in SLA for a whole panoply of classroom practices. Although these concepts proved difficult to research, they were "usefully wrong"4 in the sense that they brought meaning and interaction to the forefront and helped teachers to rethink the focus on rote memorization from the ALM era. In this sense then, as with the humanistic methodologies of the 1970 s and communicative and proficiency-based language teaching for the 1980s, Firth and Wagner's (1997) contentions that meaning depended on use, interaction, and activity captured much of the pedagogical reasoning that had become fairly well accepted methodologically through the instructional practices that had evolved 20 years previously.

\section{The Locus of Activity: Where Do Language Learning and Teaching Meet in the Classroom?}

This emerging "fit" between what had become generally accepted classroom language teaching practices in the 1990s and the theoretical constructs put forward in Firth and Wagner's (1997) article was not completely serendipitous. Underlying it was a more profound change in how language teachers and their work were understood. When they wrote that, "It may be most useful to view problems in communication as contingent social phenomena, as intersubjective entities, not as 'things' possessed by individuals" (p. 291, original italics), Firth and Wagner questioned a view of communication in applied linguistics inherited from Saussure (1922/1996), Jakobson (1960), and the structural linguists. That view, based on 
what Reddy (1979) called the conduit metaphor, portrayed interpersonal communication as a process of exchange in which speakers (or senders) encoded individual meanings in semiotic vehicles (or signs) that were then decoded by the hearers (or recipients). It contrasted with the Bahktinian view of communication as an intersubjective enterprise, which was the basis of constructivist theorizing.

Firth and Wagner (1997), in arguing that "problems in communication [are] contingent social phenomena. . intersubjective entities, not... 'things' possessed by individuals" (p. 291), framed a notion that focused not so much on the interlocutors themselves as on the spaces between them. This critique problematized the prevalent view in much SLA research of the period and advanced the view of classrooms as jointly created environments. These studies examined the differentiated roles of teacher and student, as well as the diverse roles that students assumed in interaction with one another, to develop detailed analyses and complex descriptions of classroom learning and teaching (e.g., Cazden, 1988).

More critically, however, these proposals about the intersubjective nature of the classroom and the roles of teacher and learners resonated with developing insights from research and theorizing on teacher learning that developed in the early 1990s. It had been widely observed that the ways in which teachers were prepared professionally did not reflect how they were expected to teach once in language classrooms. The saying "teachers teach as they were taught, and not as they were taught to teach" reflects that gap and the powerful role of socialization in the face of professional preparation. Graduate training generally, and methods courses in particular, tended to focus on building teaching behaviors through building of skill and techniques (Zeichner, 1999). Competence in teaching was developed through repeated practice and the new teacher's own understanding was essentially seen as a void at the heart of the teaching-learning enterprise.

All these assumptions began to change in the early 1990s as the concepts of teacher thinking or cognition began to shape research and thinking in teacher education. These perspectives brought with them the notion, which was increasingly persuasive and influential, that teachers' mental activity could be a central part of teaching, and thus of how they learned to teach (Kennedy, 1991). Three major research literature reviews in general education (Calderhead, 1987; Clark \& Peterson, 1986; Shavelson \& Stern, 1981) helped to articulate the view that teaching was more than simply behavior or activity. Classroom instruction was seen as enacting aspects of the teacher's background and beliefs ${ }^{5}$ as well as the knowledge gained through professional training. ${ }^{6}$ These constructs of teacher learning found their way into the field of language teaching a decade later, in the mid-1990s, with seminal studies of teacher decision making (Woods, 1996) and research on teacher learning in language teaching (Freeman \& Richards, 1996). In addition, they were instrumentally embedded in many teacher preparation and professional development programs through the increasingly widespread emphasis on reflective teaching (e.g., Richards \& Lockhart, 1994; Wallace, 1991).

In an interesting way, the view of the teacher as professional learner paralleled that of the student as language learner, such that Firth and Wagner's (1997) observations about the latter could be seen as applying to the former as well. When they wrote, "Reduced competence is seemingly the metric upon which discourse is interpreted by analystsregardless of interactants' interpretations, which suggest other factors" (p. 295), they were arguing for a general shift of the view of learners. They were positioning the learner (of language or of teaching) as capable of demonstrating emerging performance over time, in contrast to earlier views of such learners as showing deficits and incompetence in practice that needed to be remediated.

In a similar way, these new arguments propelled a different view of how learning unfolded in each domain. In language learning, Firth and Wagner (1997) noted that, "Misunderstandings and repair sequences. . . are not aberrations. Rather, they are integral parts of the progression of normal, conversational discourse, regardless of the social identities of the actors involved" (p. 295). Applied to teacher education, this progression of normal professional Discourse presented a different view of learning to teach. The term professional Discourse is used here in the sense of Gee's (1990) argument that identity is a social-semiotic construct negotiated through participation that is recognized as increasingly competent or proficient by members of the target Discourse community. Although learning to teach was seen as a continuum of developing expertise, both the object of professional learning (what teachers needed to know) and the process (how they learned it) were also being redefined. What had been understood exclusively as discipline-based knowledge and skills that were external to, and thus to be internalized by, the teacher-learner were now described internally. Constructs such as personal practical 
knowledge (Elbaz, 1983; Golombek, 1998), pedagogical content knowledge (Shulman, 1987), and beliefs, assumptions, and knowledge, shorthanded as BAK (Woods, 1996) shared a common basis. Although these constructs differed principally over the form taken by the knowledge, they each bridged the inner world of teachers' thoughts with the outer world of their actions. Together they established teacher knowledge as an intersubjective or contingent social phenomenon, to paraphrase Firth and Wagner, that blended elements learned through socialization, like any form of learning, with those that are explicitly taught in professional education.

The notion that teaching could be as much a cognitive as a behavioral undertaking, and that it integrated processes of thinking and acting, helped to reposition the teacher within the classroom equation. Within this view, the focus shifted to how teachers learned such a complex undertaking as teaching. The general consensus, which developed in the mid-1990s and continues today, is that the process of teacher learning is situated socially; it takes place among students, fellow teachers, and other community members. It is temporally organized in and over time, which means that there are common developmental patterns in a broad sense; teachers with certain amounts of experience share common concerns and see certain types of information as helpful in their learning. Most fundamentally, the professional learning process is contingent on an array of factors, including background and life experience, and the subject matter (Freeman \& Johnson, 1998; K. E. Johnson, 1996).

This view of teachers' professional learning has been anchored in two key aspects of the intersubjectivity mentioned by Firth and Wagner (1997). The first has to do with how the roles and goals of learning interconnect. In the study of classrooms, it is evident that teachers and students have different roles within the same environment as they take part together in the interconnected enterprise of teaching and learning (K. E. Johnson, 1995). Although they are participants in a common activity, they have differing goals for, and experiences of, that activity. The second key aspect of the intersubjectivity has to do with how the processes of teaching and learning connect, or what I have referred to here as the locus of activity. In instructed settings, learners learn in relation to-and not because of-what their teacher does or does not do. Simply put, teaching does not cause learning, although we organize most common educational practices on the assumption that it does (Freeman, 2006). The best that the activity of teaching can accomplish is to create opportunities for students to learn, an idea that challenges the central tenets of the transmission model of education and recasts the challenge to one of understanding how teaching influences learning (Freeman \& Johnson, 2004).

The concept of intersubjectivity raised by Firth and Wagner (1997) goes to the heart of classrooms. The prefix, inter-, establishes a different locale for where the processes of teaching and learning meet. Like the visual trompe-l' oeil in the etchings of Escher, the locus of activity becomes the space between them rather than the protagonists themselves. Thus, the roles of teacher and learner must be negotiated, and their respective goals are mediated by the activity itself.

\section{The Notion of Identity: Who Are Teachers and Learners in Relation to Each Other?}

Although it probably seems logical from this vantage point, it may not have been apparent a decade ago that this notion of intersubjectivity or contingency in social interactions carries in it a different concept of identity. When Firth and Wagner (1997) wrote, "The fact that NS or NNS is only one identity from a multitude of social identities, many of which can be relevant simultaneously, and all of which are motile... is, it seems fair to conclude, a non-issue in SLA" (p. 292), they were advocating a wider and more complex framing of identity that went beyond the functional definition of role as student. In the context of the mid-1990s, whether in methodology and in SLA research, the roles and identities ascribed to teacher and learner were relatively unitary and stable constructs. As Allwright (2006) observed more recently:

[There has been]... a move from a simplistic way of looking at the world of applied linguistics (e.g., thinking universally and causally that there ought to be just one best method for language teaching, for all languages, for all learners, for all teachers, and for all time) towards a recognition of the essential and irreducible complexity of the phenomenon of classroom language learning and teaching. (p. 13)

Thus people wrote about the teacher and the student as if the singularity of these roles somehow simplified the inherent localness and complexity of classroom practice.

Part of the complexity lies in the fact that these roles have always been highly circumscribed by hierarchy and position, based in value judgments that are often linked to the content. The ALM viewed the roles of teacher and 
learner as immutable, fixed within the practices of modeling dialogues, directing rapid-fire drills, and correcting precisely and immediately errors of pronunciation and form. In this way, their identities were defined by what each could (or could not) do with the target language, which helped to establish a methodological basis in language teaching for the inherent superiority of the native-speaking teacher. Although they criticized and offered alternatives to the practices, the humanistic methodologists did not fundamentally dislodge these views. Writing in 1976, Curran described how language could create a fault line that differentiated the roles of teacher and student:

As for the remote, almost god-like of the native language experts, as first viewed by the learners, we see them gradually come to share, in the learners' eyes, the common human condition. In the shared humanity of weakness and confusion, as they learn a common unknown foreign language together, there is renewed motivation for the student to identify with the expert in his language. (p. 21)

Even Communicative Language Teaching (CLT) did not dislodge the singular roles of teacher and learner and the one-dimensional identities that these circumscribed. Although the notion of communicative intent has been central in CLT practices, it is always managed through a clear hierarchy of classroom roles. Although hoping that Curran's (1976) sense of shared humanity can connect the student as language learner and the teacher as language knower, the reality seems to be that too often institutional demands and sociopolitical assumptions interpose themselves to recast the negotiated nature of the classroom enterprise. And because identities are tied directly to perceived use and expertise in the target language, "language (in)competence," as Firth and Wagner (1997, p. 292) called it, continues to define the essential identities of the users as interlocutors.

Firth and Wagner (1997) countered this view in suggesting that variations in users' language performance could well be tied to other aspects of the situation, and indeed to who the user might be trying to be in the eyes of his or her interlocutor, to "a multitude of social identities, many of which can be relevant simultaneously, and all of which are motile" as they put it (p. 292). To understand intention fully, one needs to grasp what they referred to as the "emic relevance" (p. 292) of these identities. Certainly this suggestion that context is central to interpretation was hardly a new one. A key implication in their contention, though, is the idea that such contexts could be simultaneously internal and mental just as they could be external and physical, what Cazden (1988) had termed a decade earlier as the context of the mind. Therefore, such contexts of the mind could project possibilities onto learning for both students and teachers, possibilities that Norton has called imagined identities (Kanno \& Norton, 2003).

The newfound emphasis on context of situation and of the mind as key elements in interpreting performance set out in Firth and Wagner's (1997) critique resonated, and was supported by, emerging ideas about teachers' identities that were beginning to circulate in the same time. At least three separate sets of issues converged to complicate the conventional view of who the teacher was. The first had to do content; the second with how teaching competence might be defined; and the third with how that competence might be learned. In a sense, all three sets of issues congregate around Firth and Wagner's notion of learners' language (in) competence.

For teachers, the notion of (in)competence also frames professional identity in at least three important ways. The first of these frames has to do with content and identity, and how mastery or proficiency in the target language (as content) is seen as defining teachers' identities in terms of the language/culture they are teaching. Critiquing this connection in terms of English, many would point to a symposium organized by Braine (1996) and colleagues at the 1996 TESOL convention as being a catalyst in questioning ideas of nativeness as an ideological definition of language (in)competence (Connor, 2006). Discussions problematized the long-accepted connection between nativeness and language (in)competence (Medgyes, 1992): If the teacher's identity is not simply equated to mastery of language/culture content through birth and upbringing, then how can such professional identity be defined? The relevance of their critique is substantiated a decade later by the fact that issues of what nativeness means in terms of language/culture identity, particularly with regard to English (e.g., Graddol, 2006), continues to be widely debated.

The second set of issues has to do with defining competence itself, whether in language use or in teaching. With the argument that language (in) competence might not be a unitary or stable concept, but perhaps more dynamically understood in terms of interlocutors' situations and intents, the idea of competence has become increasingly complex and problematic. Although 
evaluations of language competence can, at least arguably, be vested in the individual judgment or response of a fluent or proficient user, establishing teaching competence is not as straightforward. From a policy perspective, judgments have been vested collectively in the consensus statements of standards drawn up by various professional associations (e.g., the U.S. National Foreign Language Standards or the TESOL standards) and in the regulatory licensure requirements of individual states. On an individual basis, however, this competence is seen as a developing construct within the frame of expertise research (Berliner, 1986; Tsui, 2003). People develop competence in teaching over time and through experience and activity, much as they do in language. Just as with language users/learners, a similar argument can be made that teachers are competent at these various stages as understood within that period of their development.

The third set of issues draws parallels between becoming competent as a language user or as a teacher. As Firth and Wagner (1997) noted about language users: "L2 (in) competence... may in some situations be a resource. Anomalous forms... may be accounted for not by incompetence but by the notion of recipient design" ( $p$. 293). A similar point can be made for the development of teaching competence. The ways in which new teachers operate in their classrooms, although clearly different from those of their veteran colleagues, show a form of competent practice as understood by their contexts of situation and of the mind. In a very real sense, new teachers do what they do not as incompetent versions of their more experienced counterparts, but rather because they are competent as understood in terms of these particular aspects of their practice. Thus, the levels of excitement, exuberance, and close identification with students often demonstrated in the early years of teaching (e.g., Bullough, 1989) can be seen as evidence of competence at this level of expertise, a competence that shifts or transforms as it matures over time much as a child's language matures into adulthood speech.

In this view, identity as a learner of language or of teaching is not an inherent or even stable quality. Rather, it is shaped by participation in contexts over time. These contexts have at least two dimensions, of actual situation, or place, and of virtual membership, or mind. Firth and Wagner's (1997) arguments helped to open up this complexity and to problematize analyses of competence.

\section{CLOSING THOUGHTS}

This article makes an argument that for some readers may seem like a stretch of imagination if not of conceptions of research and of teaching. I have taken four constructs that Firth and Wagner problematized in their 1997 article, and I have sketched connections between each of these ideas and central issues in language teaching and teacher education. These connections include the focus of language teaching in the sense of what are we trying to accomplish, and how meaning is treated, which is arguably the central concern in the sense, can I mean in the new language as I do in the language(s) I already know? Taken together, these two connections force a reexamination of what I called the locus of activity, which Firth and Wagner aptly term the intersubjectivty of contingent social phenomena, quite literally how teachers and students understand each other. This intersubjectivity, or subjective interaction, is complex precisely because neither party is uniquely or reliably who they appear to be in the classroom: their identities are multiple and motile, which is the fourth connection.

I have argued here that language teaching is largely propelled by the discourse of methodology, which is expressed in terms of classroom practice, theories, and ideologies of learning. If one examines the evolution of that discourse from the unified learning theory of behaviorism as instantiated in the practices of the ALM that dominated language teaching in the 1950s and 1960s, through the theoretical pluralism of humanistic methodologies of the 1970s and 1980s, one finds many of the concepts raised in Firth and Wagner's (1997) analyses were already in play. Their article articulated, connected to, and even catalyzed certain issues of teacher and learner identity and practices in classrooms that methodologists had been raising.

The uptake of ideas outlined in the Firth and Wagner 1997 article can be traced to what I have referred to as conceptual or ideological preconditions in classroom methodologies and in teacher education. The currency of these ways of thinking about meaning and the identity of learners certainly dovetailed, if not supported, the analyses that Firth and Wagner proposed. The connection between the discourses of research and classroom practice lay in this case in teacher preparation and education, and more specifically in the shifting conceptualizations that underlay this work. Thus, I would suggest that thinking in SLA research did not drive classroom practice so much as inform 
and articulate suppositions that were in play in methodology and in teacher education.

Where classroom methodologies have often created the discoursal bridge between theory and practice, the last decade since Firth and Wagner's (1997) critique appeared has evolved a different platform for that connection. It has always been the case that teaching methods do not impose so much as they codify, and thus value, certain classroom practices. Therefore, in the absence of other, possibly competing, ways to think and to articulate those practices, methodologies held sway. The movement of the 1990s, including Firth and Wagner's critique, was to challenge those givens. In their stead, teachers' work has increasingly been interpreted in terms of their own thinking and sense-making. The future probably holds more of this direction, in which teachers' understandings of their work will become more central. The application/implication templates of research and of teaching methods will be supplanted by local rationales anchored in teachers' views of their practices, within the larger social and political settings of that work.

At its most basic, however, the lack of fit between research and classroom practice seems to turn on limitations, and indeed simplifications, that are inherent in any good research and are a function of the research process itself (Kennedy, 1997). Research findings tend to narrow and even purify the messy, local complexity of teachers' classrooms, and thus they chafe with the specific ways in which thinking and acting combine for teachers in their work (Freeman, 1996). Similarly, classroom teaching is generally more circumscribed by meaning and value in the broadest sense-by personalities, politics, and the dynamics of power - than by objective reasoning or data about learning. So approaching the research/practice relationship by asking how the one shapes the other is perhaps less productive than examining why and how the "fit" between them evolves. In the sense that research and practice "fit" together, they make connections that influence thinking, theorizing, and study, on the one hand, and doing, activity, and practice, on the other. In the sense that research and practice are "fitting of" one another, they each deserve such interconnection, however tenuous and serendipitous.

\section{NOTES}

${ }^{1}$ In this article, I use the relative shorthand, language teaching, to include contexts of second/foreign language teaching and language teacher education to refer to second/foreign language teacher education. When I use the terms, teacher or classroom, I mean to refer to language teachers and the language classrooms.

${ }^{2} \mathrm{I}$ use the term preconditions here in the sense of Strober and Tyack's (1980) now-classic historical analysis of the feminization of teaching. In critiquing the straight economic argument of supply and demand that had been used to explain why U.S. public school teaching came to be viewed as women's work in the early 19th century, these authors examined the ideological and conceptual factors that supported that transformation. They referred to these factors as preconditions for the change. I find theirs a compelling way to look at how new social norms are introduced, established, and influence practices.

${ }^{3}$ It bears noting, as the reader will see in the references to this article, that a great many citations come from books originally published by Newbury House Publishers. This connection is not coincidental because the original vision of that publisher was to advance knowledge in second/foreign language teaching and learning. Throughout the 1980s and into the early 1990s, Newbury House played a key role in advancing the voices of language teaching practice and SLA research.

${ }^{4}$ I heard the phrase "usefully wrong" first applied to Shulman's (1987) concept of pedagogical content knowledge, in the sense that it stimulated a broad reexamination of teacher knowledge, although the concept itself proved very difficult to research or document.

${ }^{5}$ The study of beliefs, particularly in language teaching, has a complex history because there are no standard definitions for the concept either as descriptive notion or research tool (see Bernat \& Gvozdenko, 2005; also Borg, 2003; and Woods, 1996).

${ }^{6}$ This work had been in some ways foreshadowed by research on beliefs in foreign language teaching about communicative fluency (De Garcia, Reynolds, \& Savignon, 1976) as well as by Kern's (1995) work on beliefs about language learning, the major distinction being that the teacher cognition research summaries of the late 1980s addressed the place of thinking generally in teachers' work, of which beliefs about learning, content, or instruction were a subset.

\section{REFERENCES}

Allen, J. P. B., \& Corder, P. S. (1973). The Edinburgh course in applied linguistics. Oxford: Oxford University Press.

Allwright, D. (2006). Six promising directions in applied linguistics. In S. Gieve \& I. Miller (Eds.), Understanding the language classroom (pp. 11-17). Basingstoke, UK: Palgrave Macmillan.

Bahktin, M. (1981). The dialogic imagination (C. Emerson \& M. Holquist, Trans.). Austin: University of Texas Press.

Berliner, D. (1986). In pursuit of the expert pedagogue. Educational Researcher, 15, 5-13.

Bernat, E., \& Gvozdenko, I. (2005). Beliefs about language learning: Current knowledge, pedagogical implications, and new research directions. TESLEJ, 9, 1-21. 
Blair, R. (Ed). (1982). Innovative approaches to language teaching. Rowley, MA: Newbury House.

Borg, S. (2003). Teacher cognition in language teaching: A review of research on what language teachers think, know, believe, and do. Language Teaching, 36, 81-109.

Borg, S. (2005). Experience, knowledge about language, and classroom practice in teaching grammar. In N. Bartels (Ed.), Applied linguistics and language teacher education (pp. 325-340). New York: Springer.

Braine, G. (1996, March). Nonnative speakers in their own voices. In Braine et al., Nonnative speakers in their own voices. Panel conducted at the 30th Annual TESOL Convention, Chicago, IL.

Brown, H. D. (1987). Principles of language teaching and learning (2nd ed.). Englewood Cliffs, NJ: Prentice Hall.

Brumfit, C., \& Johnson, K. (1979). The communicative approach in language teaching. Oxford: Oxford University Press.

Bruner, J. (1996). The culture of education. Cambridge, MA: Harvard University Press.

Bullough, R. (1989). First-year teacher: A case study. New York: Teachers College Press.

Calderhead, J. (1987). Exploring teachers' thinking. London: Cassell.

Candlin, C. N., \& Widdowson, H. (1988). Language teaching: A scheme for teacher education. Oxford: Oxford University Press.

Cazden, C. (1988). Classroom discourse. Portsmouth, NH: Heinemann.

Chomsky, N. (1959). Review of Verbal behavior by B.F. Skinner. Language 35, 26-58.

Clark, C. M., \& Peterson, P. L. (1986). Teachers' thought processes. In M. C. Wittrock (Ed.), Handbook of research on teaching (3rd ed., pp. 255-296). New York: Macmillan.

Clarke, M. (1994). The dysfunctions of theory/practice discourse. TESOL Quarterly, 28, 9-26.

Cochran-Smith, M., \& Lytle, S. (1993). Inside-outside: Teacher research and knowledge. New York: Teachers College Press.

Connor, U. (2006). Fear and loathing on the convention stage. Essential Teacher, 3, 22-25.

Curran, C. (1976). Counseling-learning in second languages. Apple River, IL: Apple River Press.

De Garcia, R., Reynolds, S., \& Savignon, S. (1976). Foreign-language attitude survey. Canadian Modern Language Review, 32, 302-304.

Elbaz, F. (1983). Teacher thinking: A study of practical knowledge. New York: Nicols Publishing.

Firth, A., \& Wagner, J. (1997). On discourse, communication, and (some) fundamental concepts in SLA research. Modern Language Journal, 81, 285-300.

Firth, A., \& Wagner, J. (1998). SLA property: No trespassing. Modern Language Journal, 82, 90-94.

Freeman, D. (1996). The "unstudied problem": Research on teacher learning in language teaching In D. Freeman \& J. C. Richards (Eds.), Teacher learning in language teaching (pp. 351-378). New York: Cambridge University Press.
Freeman, D. (1998). Doing teacher-research: From inquiry to understanding. Boston: Heinle \& Heinle.

Freeman, D. (2002). The hidden side of the work: Teacher knowledge and learning to teach. Language Teaching, 35, 1-14.

Freeman, D. (2006). Teaching and learning in the 'age of reform': The problem of the verb. In S. Gieve \& I. Miller (Eds.), Understanding the language classroom (pp. 239-262). Basingstoke, UK: Palgrave Macmillan.

Freeman, D., \& Johnson, K. E. (1998). Reconceptualizing the knowledge-base of language teacher education. TESOL Quarterly, 32, 397417.

Freeman, D., \& Johnson, K. E. (2004). Towards linking teacher knowledge and student learning. In D. Tedick (Ed.), Second language teacher education: International perspectives (pp. 73-95). Mahwah, NJ: Erlbaum.

Freeman, D., \& Richards, J. C. (1996). Teacher learning in language teaching. New York: Cambridge University Press.

Gattegno, C. (1976). The commonsense of teaching foreign languages. New York: Educational Solutions.

Gattegno, C. (1987). The science of education. New York: Educational Solutions.

Gee, J. (1990). Social linguistics E literacies: Ideology in discourses. Philadelphia: Falmer.

Giroux, H. (1988). Teachers as intellectuals: Towards a critical pedagogy of learning. New York: Praeger/Greenwood.

Golombek, P. (1998). A study of language teachers' personal practical knowledge. TESOL Quarterly, 32, 447-464.

Graddol, D. (2006). English next: Why global English may mean the end of 'English as a foreign language.' London: The British Council.

Jakobson, R. (1960). Style in language. Cambridge, MA: MIT Press.

Johnson, K. E. (1995). Understanding communication in second language classrooms. New York: Cambridge University Press.

Johnson, K. E. (1996). The role of theory in L2 teacher education. TESOL Quarterly, 30, 765-771.

Johnson, K. E. (1999). Understanding language teaching: Reasoning in action. Boston: Heinle \& Heinle.

Johnson, R. K. (1989). The second language curriculum. Cambridge: Cambridge University Press.

Kanno, Y., \& Norton, B. (2003). Imagined communities and educational possibilities: Introduction. Journal of Language, Identity, and Education, 2, 241249.

Katz, S., \& Watzinger-Tharp, J. (2005). Towards an understanding of applied linguists in foreign language departments. Modern Language Journal, 89 , 490-502.

Kelly, G. W. (1976). 25 centuries of language teaching. Rowley, MA: Newbury House.

Kennedy, M. (1991). An agenda for research on teacher learning. East Lansing: National Center for Research on Teacher Learning, Michigan State University. 
Kennedy, M. (1997). The connection between research and practice. Educational Researcher, 26, 4-12.

Kern, R. G. (1995). Students' and teachers' beliefs about language learning. Foreign Language Annals, 28, 71-92.

Kleinsasser, R. (1992). A tale of two technical cultures: Foreign language teaching. Teaching and Teacher Education, 9, 373-383.

Krashen, S. (1981). Second language acquisition and second language learning. Oxford: Pergamon Press.

Krashen. S., \& Terrell, T. (1983). The natural approach. San Francisco: Alemany Press.

Larsen-Freeman, D. (1986). Techniques and principles in language teaching. New York: Oxford Press.

Larsen-Freeman, D., \& Long, M. (1989). An introduction to second language acquisition research. White Plains, NY: Longman.

Lozanov, G., \& Gateva, E. (1988). The foreign language teacher's suggestopedic handbook. New York: Gordon Beech.

McLaughlin, B. (1987). Theories of second language learning. London: Edward Arnold.

Medgyes, P. (1992). Native or non-native: Who's worth more? ELT Journal, 46, 340-349.

Nunan, D. (1989). Understanding language classrooms: A guide for teacher-initiated action. London: Prentice Hall-International.

Omaggio Hadley, A. (1993). Teaching languages in context. Boston: Heinle \& Heinle.

Ortega, L. (2005). For what and for whom is our research? The ethical as transformational lens in instructed SLA. Modern Language Journal, 89, 427443.

Reddy, M. J. (1979). The conduit metaphor: A case of frame conflict in our language about language. In A. Ortony (Ed.), Metaphor and thought (pp. 284324). Cambridge: Cambridge University Press.

Richards, J. C. (1975). Error analysis: Perspectives on second language acquisition. New York: Longman.

Richards, J. C., \& Lockhart, C. (1994). Reflective teaching in second language classrooms. New York: Cambridge University Press.
Richards, J. C., \& Nunan, D. (1990). Second language teacher education. New York: Cambridge University Press.

Richards, J. C., \& Rodgers, T. (1986). Approaches and methods in language teaching. NewYork: Cambridge University Press.

Saussure, F. de. (1966). A course in general linguistics (C. Bally \& A. Sechehaye, Trans). New York: McGrawHill. (Original work published 1922)

Seliger, H., \& Long, M. (1983). Classroom oriented research in second language acquisition. Rowley, MA: Newbury House.

Selinker, L. (1972). Interlanguage. International Review of Applied Linguistics in Language Teaching, 10, 209-231.

Shavelson, R. J., \& Stern, P. (1981). Research on teachers' pedagogical thoughts, judgments, decisions, and behavior. Review of Educational Research, 51, 455-498.

Shulman, L. (1987). Knowledge and teaching: Foundations of the new reform. Harvard Educational Review, 57, 1-22.

Stevick, E. (1980). Teaching languages: A way and ways. Rowley, MA: Newbury House/Heinle \& Heinle.

Strober, M., \& Tyack, D. (1980). Why do women teach and men manage? A report on research on schools. Signs, 5, 494-550.

Tsui, A. (2003). Understanding expertise in teaching. New York: Cambridge University Press.

Walberg, H. (1971). Decision and perception: New constructs in research on teaching effects. Cambridge Journal of Education, 7, 12-20.

Wallace, M. (1991). Training foreign language teachers: A reflective approach. Cambridge: Cambridge University Press.

Woods, D. (1996). Teacher cognition and language teaching. New York: Cambridge University Press.

Yates, R., \& Muchisky, D. (2003). On reconceptualizing teacher education. TESOL Quarterly, 37, 135147.

Zeichner, K. (1999). The new scholarship in teacher education. Educational Researcher, 28, 4-15. 